\title{
Established ideas from established institutions: austerity and structural reforms in the Finnish economic policy debate
}

\author{
Timo Harjuniemi (University of Helsinki) \& Marko Ampuja (University of Tampere)
}

Instead of alternative economic ideas or institutional shifts, the post-financial crisis conjuncture has witnessed the persistence of neoliberal ideas and the strengthening of the institutions implementing them. Instructed by ideational institutionalism, this article analyzes the interplay between ideas and institutions by examining the public debate on economic policy in Finland during the euro crisis. We show how ideas formed by the dominant institutions of Finnish economic policy-making dominated the debate in the leading Finnish newspaper Helsingin Sanomat in the years 2009-2014. The media and the elites coalesced around a consensus built by the Ministry of Finance and EU institutions, which demanded austerity and structural reforms to the Finnish economy. Our findings support claims that established institutional forces prevent ideational shifts even during major crisis periods. The media takes part in this through its unwillingness to provide alternative viewpoints on consensual political issues, thus strengthening a post-democratic public sphere.

KEYWORDS: austerity, structural reforms, Finland, media, ideas, institutionalism

\section{Introduction}

In the EU in particular, the dominant response to the global economic crisis that erupted in 2008 has been to consolidate neoliberal austerity and structural reform policies, which aim to reduce wages and public spending, cut back on social services and liberalize market regulations. Authorities repeatedly advocated such policies as the only possible way out of the current predicament, a proven method by which states can restore 'business confidence' after decades of reckless spending by governments. These beliefs have been strongly criticized by a number of heterodox and even mainstream economists, both on the grounds that they do not present an accurate picture of the causes of the crisis and because austerity policies have only made matters worse (e.g., Blyth 2013; Quiggin 2010). Yet, despite these critiques regarding 
the actual market-based causes of the crisis, and the economically and socially deleterious consequences of austerity, the 'dominant forms of economic regulation persist, apparently impervious to evidence, evaluation or the merits of alternatives’ (Davies 2016, 121).

Such inertia has defied the expectations of many political economists, among them institutionalists of different persuasions, who have emphasized that exogenous factors, such as economic crises of this magnitude, have historically been a major source of institutional change and the emergence of new policy paradigms (P. Hall 1993; Blyth 2001; Hay 2001). Crises tend to support new ideas that challenge conventional wisdoms, but such potentialities by necessity clash with established institutional settings and their ideological make-ups in specific national contexts (Schmidt 2008, 307; Baker and Underhill 2015). In the end, the success (or lack) of new ideas is dependent upon political conditions and the balance of power between divergent political and economic agents, interests and institutions.

In this article, we will critically analyze how the public interplay between ideas and institutions has played out in Finland, a northern member of the EU and eurozone. It offers an interesting case since 'of all the European countries that turned austere, Finland was, apart from the UK, the only one that volunteered for it' (Blyth 2017, 7). One factor that accounts for this is that Finland's history of economic policy-making embodies, despite its reputation as a Scandinavian-style welfare state, persistent non-Keynesian features and a strong consensus-seeking orientation (Pekkarinen 1989; Pekkarinen and Heinonen 1998; Kantola and Kananen 2013). We will analyze how this tradition affected the responses of Finnish political and economic elites to the economic crisis. The article contributes to institutionalist research by examining how leading Finnish politicians and economic experts, together with the mainstream media, produced remarkably one-sided understandings of the crisis. Support for austerity and structural reforms are evident via the policy ideas stemming from the Finnish Ministry of Finance (MoF) and EU as rational responses to the economic predicament; policy formulations that deviated from such reforms received little coverage. Thus, we argue that the staying power of neoliberal ideas is partly due to the media, which is incapable of producing alternative viewpoints to the political viewpoints supported by a dominant elite consensus (see Hallin 1984; Gibson 2004; Lounasmeri 2010).

Empirically, we will use articles on economic policy published in Helsingin Sanomat (HS), the leading and most politically influential daily newspaper in Finland. Our data covers the 
years 2009 to 2014, the period when important economic policy decisions were made in the country on how to deal with the economic crisis, paving the way for the liberal structural reforms and austerity measures of the current right-wing coalition government. Theoretically, we will reflect on the implications of our findings within the context of ideational institutionalism, which is interested in the role that ideas play in maintaining or changing dominant political-economic institutions (Hay 2001; Blyth 2002; Koning 2016).

The article is structured as follows. First, we will discuss the main features of ideational institutionalism and the role of the media in that context. We will then examine the following questions: What were the dominant economic policy ideas and responses voiced in $H S$ between the years 2009 and 2014, and who were the main agents voicing such ideas? To what extent were such ideas challenged in HS? To answer the questions, we will reflect on a broader question concerning the interplay between ideas and institutions. Rather than showing the active role of new ideas in inducing change during times of crisis, our findings testify to the power of long-standing institutional frameworks guiding economic policy in Finland. We will conclude the article by focusing on how the lessons that can be learned from Finland relate to broader 'post-democratic' developments in liberal capitalist democracies.

\section{Ideational Institutionalism and the Media}

Since the 1980s, a significant number of political economists and institutional researchers in sociology and political science have been studying the question of how ideas influence policy making and, more specifically, how they contribute to changes in economic policy paradigms (e.g., P. Hall 1989; Blyth 1997; Campbell 1998; Blyth, Helgadottir, and Kring 2016). Such studies have been conducted as part of ideational research on historical institutionalism, sociological institutionalism, and discursive institutionalism. For reasons of convenience, we will refer to this variety of institutionalism as ‘ideational institutionalism’ (Hay 2001; Koning 2016). It is an 'internally varied subtype' of institutionalist research, one which is unified by its advocates' interest in the importance of ideas (e.g., values, norms, economic theories, public philosophies, elite policy prescriptions) in processes of institutional change (Koning 2016, 647).

The turn towards ideas in institutionalist scholarship was motivated by two interrelated factors. First, there was the growing perception that existing institutionalist approaches were not good at explaining and conceptualizing change. According to critics, they offered a static 
and deterministic view of institutions that over-emphasized stability at the expense of developing a more dynamic view on how institutions evolve over time and how political economic paradigms can change, sometimes in radical ways (Schmidt 2008, 304; Koning 2016, 639). Campbell (1998, 380) argued that while historical institutionalists had examined the role of ideas in policy making, they have typically done so only from the standpoint of how existing institutions, rules and norms limit their impact, instead of studying how ideas facilitate action.

Secondly, such critiques are tied to the common sociological dilemma of the relationship between structure and agency. According to institutionalists prioritizing the explanatory role of ideas, objective conditions are not enough to explain policy changes, nor do ideas reflect institutional interests mechanistically. Institutionalists of this variety make such claims in order to distance themselves from what they perceive as an overly socialized understanding of political action, which focuses too much on the causal role of structural factors. Thus, for instance, Peter Hall $(1993,290)$ has argued that 'organized interests ... do not simply "exert power”; they acquire it by trying to influence the political discourse of their day.'

Hence, ideational institutionalists have aimed to develop a more 'agent-centered approach' (Schmidt 2008, 305), which directs attention to the role of elites (and, to a lesser extent, other less powerful groups) and the means by which they 'not only stabilize but also subvert prevailing orders' (Widmaier 2016, 340). Ideas matter precisely because they are connected to social power and attempts to both consolidate the existing institutional order and to undermine it. Carstensen and Smith (2016, 320) define ideational power 'as the capacity of actors (whether individual or collective) to influence actor's normative and cognitive beliefs through the use of ideational elements.' Such influence does not necessarily refer only to changes in cognitive frames, since ideas can also instigate fundamental institutional changes, especially in times of economic crisis, when 'the politics of ideas becomes increasingly important' (Blyth 2001, 3-4; see also Baker and Underhill 2015, 381).

However, ideational institutionalists constantly need to qualify their emphases on the importance of agents and ideas versus structures and interests. In his analysis of the rise of supply-side policies in the United States, Campbell $(1998,379)$ points out that referring to 'ideas alone' is unhelpful when trying to explain such developments. 'Material interests and [the] resources backing them were important too,' since 'supply-side ideas captured the 
imagination of policy makers in part, but not entirely, because they were connected to the organizational resources of powerful political and economic interests' (379). Groups with more resources obviously have a better chance of getting their ideas across in elite decisionmaking circles and of receiving broader publicity. By the same token, ideational scholars have often acknowledged the ways in which former policy decisions and pre-existing institutional structures constrain possibilities for change and delimit possible courses of action (Campbell 1998, 378; Blyth 2001, 4; Koning 2016, 641).

Accordingly, it does not make sense to give any prima facie theoretical precedence to ideational change when assessing developments in economic policy-making in different national contexts. Depending on the context, stability may describe more adequately the state of affairs than change, and even major economic crises do not necessarily lead to significant policy paradigm shifts. The extent to which established institutional forces limit ideational change has become increasingly evident in policy responses to the current global economic crisis. Such forces have demonstrated the resilience of and, in fact, further promotion of neoliberal prescriptions concerning fiscal consolidation in the eurozone, especially through the dominance of influential non-majoritarian institutions, such as the European Commission or the European Central Bank, together with pacts that regulate the European Monetary Union (Schmidt and Thatcher 2014; Streeck 2015). It is thus vital for critical ideational research to take into account the interplay between ideas and institutions (which often represent highly organized interest groups) when analyzing stability and change in policy-making.

Institutionalist research is organically connected to the study of the media, whose role is essential in terms of ideational struggles between various agents and institutions (Carstensen and Schmidt 2016, 325-327). In conveying ideas, the media has both the role of 'coordinating' ideas among policy actors and 'communicating' ideas between political actors and the wider public (Schmidt 2008). The media constitutes the single most important sphere for the dissemination of information about the economy and for the legitimation of economic policies (Schranz and Eisenegger 2011; Mylonas 2012). The media is not only an apparatus of elite public persuasion, but also a network for inter-elite communication that allows influential groups to develop shared viewpoints on economic and political issues (Davis 2003). The mainstream media plays a key role in connecting elite groups with one another and/or the broader public; it gives elites a space to wield 'ideational power' (Carstensen and Schmidt 2016, 325-327). 
However, the media is not a neutral public arena that merely organizes other institutional actors' voices. It is also itself a political force and institutional actor, since the ways in which journalists frame economic crises, for instance, shape broader policy debates and responses (Schifferes and Roberts 2015, xvi-xvii). Such framing does not by necessity lead to ideational contestation, but may instead serve to further entrench previously established policy paradigms. By focusing on the role of the media and the need to empirically analyze the interplay between ideas and institutions in specific national contexts, our analysis shows how Finnish political-economic elites and the media worked in tandem to consolidate highly uniform perceptions concerning the crisis and how to respond to it. In part this was to be expected, since the mainstream media are an integral part of those elites, due to structures of ownership, the influence of corporate advertisers and the conservative political orientation of media owners, all of which tend to make news journalism hostile to criticism of the status quo (Herman and McChesney 1997, 6). However, the ideational uniformity that characterizes our data must also be understood within the historical context of Finnish economic policy-making and general EU economic regulations.

\section{Data and method}

Our analysis examines the dynamics between ideas and institutions by examining how economic policy has been debated in HS. Since its establishment in 1904, HS has played a fundamental role in the Finnish public sphere. Not only is $H S$ the largest daily subscription newspaper in Finland and in the Nordic countries (Nordicom 2017), it also belongs to the small circle of Finnish elite media, actively promoting what Lounasmeri $(2010,5)$ calls 'the consensual Finnish political culture' where political and economic elites as well as journalists coalesce around ideas that are believed to serve the national interest (see also Hallin 1984). Thus, the public discussions in HS are seminal for understanding Finnish economic policy discourse as a whole.

Our data consists of articles published in the domestic and economy sections of $H S$ between 2009 and 2014. This period was crucial with respect to Finnish policy responses to the financial crisis, and the policy lines drawn during this time have been implemented by the current government, which assumed office in 2015. Our primary material for this article has been collected around two yearly events concerning the Finnish budget. The first event is the annual revision of the budget frame in March-April.1 The second yearly event is when the 
MoF publishes its proposition for the next year's budget in late July or early August. By focusing on these two events, we were able to pinpoint the moments receiving more coverage of economic policy, including commentary by representatives of various institutions concerning economic prospects and problems. HS's electronic archive was searched using various keywords on economic policy and the budget.2 The search periods were confined to two-week periods. We thematically narrowed the data down to articles that included reasoning about the causes of the economic problems in Finland and/or the appropriate remedies. The total number of articles used in our analysis was 119 (see table 1).

\begin{tabular}{|c|c|}
\hline \multicolumn{2}{|l|}{ Spring (budget allocation) } \\
\hline 2009 & 5 \\
\hline 2010 & - \\
\hline 2011 & 9 \\
\hline 2012 & 12 \\
\hline 2013 & 17 \\
\hline 2014 & 11 \\
\hline 2009 & 6 \\
\hline 2010 & 15 \\
\hline 2011 & 8 \\
\hline 2012 & 13 \\
\hline 2013 & 12 \\
\hline 2014 & MoFticles \\
\hline
\end{tabular}

Table 1. Articles focusing on the annual budget procedure

Our primary method of analysis was a textual analysis of the articles (Fürsich 2009, 241). This method allowed us to identify the dominant 'programmatic' (Baker and Underhill 2015, 1) economic ideas concerning problems with the Finnish economy and the proposed solutions. Furthermore, we were able to interpret these ideas within the institutional and historical context of Finnish economic policy-making.

Moreover, we identified and analyzed the most prominent sources (quoted directly or referred to in the article) in the debate and which agents were provided with the ability to define the 
nature of the crisis and prescribe appropriate responses. As our secondary material, we conducted a keyword search on certain economic policy terms throughout the whole period (2009-2014) in HS, and counted the frequency of their occurrence in the articles, to further illustrate and highlight the kinds of ideational shifts that took place during the crisis.

\section{Findings}

\section{Who has agency?}

When assessing the sources and their prominence in our data from a quantitative perspective, various elite groups were provided with the most space to interpret and define the economic policies surrounding the budgetary process (figure 1). Government ministers were the most popular source group, followed by other politicians and representatives of Finnish labor and employer organizations, all of whom have traditionally supported a corporatist and consensusseeking agenda (Vesa 2016). Among governmental sources, the prime minister and the minister of finance were clearly the most visible actors in the economic debates. The voices of ministers and other representatives of governing parties outweighed those of politicians from opposition parties. Economists formed a notable source group as well. Economists representing research institutions (which traditionally have closed-knit ties with either employer or labor organizations) formed the most prominent part of this group, followed by bank and university economists.

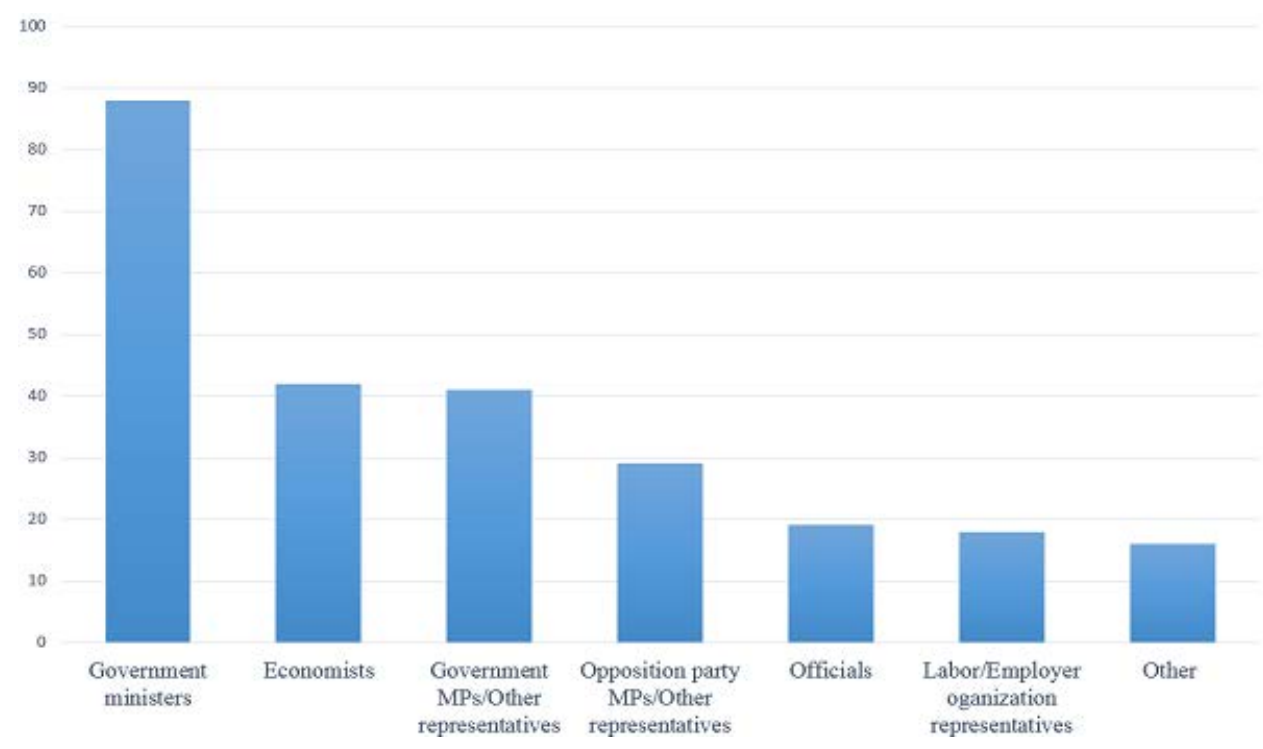

FIGURE 1. The source groups cited most often in articles on the budget, 2009-2014. 
Such figures by themselves do not, however, speak to relationships of power between different institutional actors or the nature of public discourses and ideas disseminated by the media. By examining these issues further, we can better understand why there has been so little change in Finnish economic policy recently. In the following section, we turn our attention to the nature of ideas voiced by these dominant actors.

\section{Limited Keynesianism trumped by the MoF line}

As a number of historical institutionalists have pointed out, the financial crisis induced a revival of active fiscal policies in the United States and Western Europe that were widely accepted as rational solutions to the crisis (Farrell and Quiggin 2012; Blyth 2013, 54-56). Under the guidance of the European Commission, EU countries formally committed themselves to stimulus packages constituting 1\% of their GDP (Farrell and Quiggin 2012, 24). Therefore, in line with other EU members, Finland engaged in fiscal stimulus in order to curb the effects of the global crisis (Kuismanen and Spolander 2012), even though in its budget proposal for 2010 the MoF expressed concerns that this would violate EU criteria regarding public deficits (Ministry of Finance 2009).

This Keynesian surge was also clearly visible in the pages of HS. In March 2009, Jyrki Katainen, the minister of finance from the right-wing National Coalition Party, noted that the level of public debt was on the rise, pointing out that it was 'being used as a tool to cushion the effects of the recession' (HS, March 17, 2009). While the rise of government debt was noticed at this stage, policy proposals pointed to an active fiscal stance. As one $H S$ journalist noted, 'It is all right to go into debt now' (HS, March 17, 2009). In another news article, an often-cited economist (Sixten Korkman, a former managing director of the Research Institute of the Finnish Economy) argued at length that 'the state should not be alarmed and start to cut its expenditures,' but should instead 'stimulate the economy and support employment' (HS, March 26, 2009).

These immediate responses to the crisis differed from the dominant policy ideas during the severe depression of the 1990s, when Finnish decision-makers - led by the MoF - quickly adopted austerity measures (Kantola and Kananen 2013). In HS, Raimo Sailas, a powerful official from the MoF, argued that allowing government debt to rise is the most 'rational way' to deal with the current situation (HS, March 31, 2009). As a sign of things to come, however, he already laid the rationale for the forthcoming austerity policies, since over time there will 
be no alternative to strict budgetary discipline: 'I hope that there will be an understanding across party lines that in the next elections, it would be irresponsible to make promises about increasing expenditure’ (HS, March 31, 2009).

Traditionally, the ideas adopted by high-ranking MoF (Ministry of Finance) officials have steered Finnish economic policy-making (Pekkarinen and Heinonen 1998, 94-99; Määttä 2005, 60; Kantola and Kananen 2013, 816; Vesa 2016, 21). Powerful bureaucrats have guarded the national consensus in Finnish economic policy-making since the $19^{\text {th }}$ century, and after the Second World War, economic planning was centralized in the MoF (Pekkarinen and Heinonen 1998, 88-94). The economic crisis of the 1990s strengthened the power of the MoF: it developed into a policy entrepreneur for multi-party government coalitions. In the midst of the crisis, the ministry assumed the role of cutting public finances and, more importantly, devised the idea of long-term budgetary allocations based on Schumpeterian ideas regarding national competitiveness and strict budgetary discipline (Kantola and Kananen 2013, 816-817). This was a radical shift from the earlier budgetary system; now, the role of the yearly budgetary negotiations became less important and it became easier to curb public expenditures (Heikkinen and Tiihonen 2010, 342-354). Accordingly, the objectives of economic policy and the limits placed on government expenditure are today determined at the beginning of the parliamentary term. The long-standing ideas concerning the importance of national competitiveness and balanced budgets, as well as the institutional arrangements that support them, have offered fertile ground for two themes that have dominated economic policy in Finland in recent years: the need for austerity and structural reforms.

From late 2009 onwards, the long-term negative prospects of public debt have been given more consideration and the perception that stimulus measures should not derail the long-term objective of balanced public finances became more pronounced. In July 2009, Jyrki Katainen of the National Coalition Party warned that Finland should not become 'excessively indebted' and that 'we should not start to live recklessly,' because 'the deeper we go into the crisis, the bigger will be the job of balancing the economy after the crisis’ (HS, July 29, 2009). Yet, around this time, the mainstream political opinion was that the crisis was temporary, and that rising public debt would not necessitate immediate 'significant cuts, because they would only deepen the crisis,' as argued by the then Prime Minister Matti Vanhanen of the Centre Party (HS, July 31, 2009). 
In 2010, the MoF in its budgetary proposal for 2011 expressed concern over the balance of public finances and stated that finances would gradually have to be tightened (MoF 2010). This shift towards austerity was made in tandem with other EU countries, while the ECB, the German government, and a number of influential economists in particular were arguing that stimulus would have to make room for a steadfast reduction of fiscal deficits (Blyth 2013, 5462; Whiteside 2016, 362-363).

At this stage, HS began to emphasize the importance of fiscal discipline and structural reforms. The public must prepare itself for belt-tightening, and references to fiscal stimulus became much rarer and more sporadic, never enjoying the same positive appeal as previously (see figure 2).

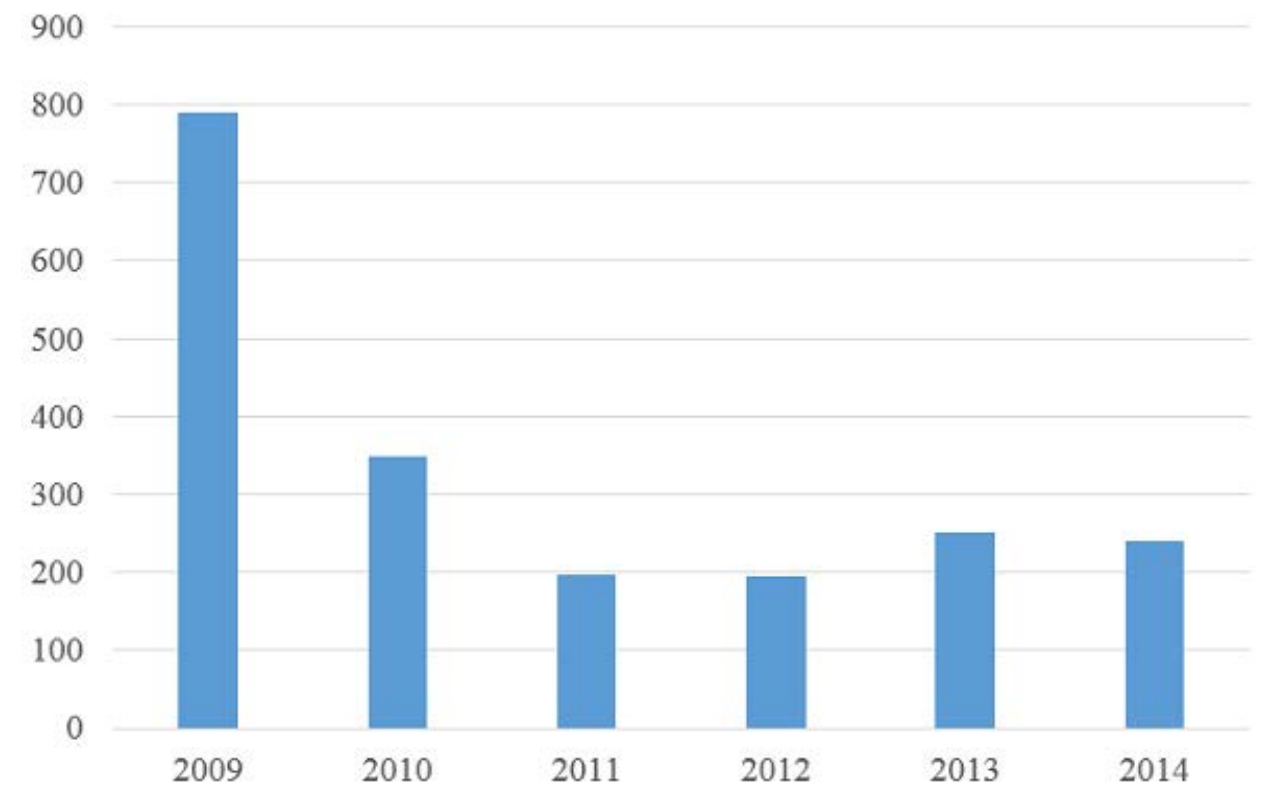

FIGURE 2. Articles with the word "stimulus," 2009-2014.

The institutional power of the MoF was evident on many occasions in our data, although usually not directly via its representatives. Jyrki Katainen became PM in 2011 and his government committed itself to austerity and structural reforms that were deemed necessary to ensure economic growth and sustainable public finances (Kuismanen and Spolander 2012). Accordingly, the prime minister and minister of finance mostly repeated policy prescriptions devised by the MoF. For example, when Katainen worried about the unity in his government for carrying through austerity measures, he pleaded that 'when it comes to the budget, it would be best if we do not deviate much from what the MoF has proposed' (HS, August 27, 
2011). Jutta Urpilainen from the Social Democratic Party was sworn in as the finance minister, but her party affiliation did not result in any deviation from MoF policy ideas. If anything, she wanted to hasten the policy shift (HS, August 18, 2011). For her, the fact that the economic outlook became bleaker towards the end of 2011 worked as a case to push for more austerity. Both Urpilainen and the MoF wanted to 'press ahead with the 2.5 billion euros of spending cuts and tax hikes’ and were worried about public debt (HS, August 23, 2011).

Only once did HS present mildly criticize the MoF by noting that it had not told which figures its economic growth forecasts were based on (HS, August 19, 2011). The following quote from Minister of Economic Affairs Jan Vapaavuori, from the National Coalition Party, highlights the fundamental ideational power possessed by the MoF:

Well, it is common to throw ideas around in Finland. But we need to remember that the Ministry of Finance has traditionally guaranteed stability and security, so that trust in the economic policy line has stayed strong. (HS, August 9, 2014)

The key politicians that $H S$ interviewed and gave space to did not enthusiastically support austerity. Instead, austerity was offered more as a bitter pill that needed to be swallowed: ‘times are tough and decisions are painful,' Urpilainen stated (HS, March 30, 2014). At times, the discussions on austerity were accompanied by worries, especially by social-democratic politicians, over what would happen to the Finnish welfare state. Yet, these were merely discordant notes drowned by the chorus of voices that presented austerity as a necessary policy. Indeed, when economic indicators continued to worsen in 2013, this did not lead to an argument for fiscal stimulus or to the loosening of economic targets concerning debt and deficits. Many articles between 2012 and 2014 supported the main narrative: 'There is no end to budget deficits' (HS, August 8, 2012); 'Urpilainen: the need to make cuts may have increased' (HS, March 14, 2013); or 'The pressure to tighten public finances grows' (HS, March 19, 2014).

These dominant economic assessments coalesced around the argument that there were no alternatives to the MoF line. Urpilainen argued that 'all Finns should understand that past times will never return’ (HS, August 8, 2013). HS, citing a right-wing politician, echoed this line through the claim that 'our finances cannot support a public sector of this size' (HS, August 14, 2014). 


\section{$E U$ as the austerity watchdog}

Together with the MoF and the leading politicians who supported its views, representatives of the EU and ECB were prominent agents in public discussions on economic policy. These institutions were also present indirectly, via references to the rules and pacts of the European Monetary Union (EMU), which strongly restrict Finnish economic policies. HS reminded its readers of the EMU's specifications that public debt could not constitute over $60 \%$ of the GDP and that any increases needed to be offset by cuts in public spending combined with economic reforms (e.g., HS, March 25, 2009; HS, March 18, 2010; HS, August 24, 2010; HS, March 26, 2012). These criteria and other EU-level financial agreements were treated as rules that could not be broken: failure to abide by them would result in more austerity.

In March 2010, HS noted the EU Commission's evaluation that Finland had stimulated the economy so much that its public sector showed a deficit, and it urged the country to 'define a strategy for public-sector finances that will restore the sustainability of the economy' (HS, March 18, 2010). In July 2010, Olli Rehn, the commissioner responsible for economic and monetary affairs at the European Commission, told HS that even though Finland was not Greece, it needed to start 'overhauling' its public finances in 2011 and in the coming years. 'In practice, this means spending cuts, tax hikes, productivity improvements, and extending working careers' (HS, July 23, 2010). Such exhortations clearly show the public authority given to leading EU decision-makers by HS on matters pertaining to Finnish finances.

In July 2010, in support of the MoF line, HS reported the observations of Jean-Claude Trichet, then head of the ECB: 'industrial countries throughout the world need to give up stimulating their economies, cut public spending, and raise taxes' and 'we should not waste time in dismantling' the stimulus measures (HS, July 24, 2010). By showcasing Trichet as a key international expert on how governments should deal with the economic crisis, $H S$ echoed the emerging consensus of both Finnish and the eurozone elites: active fiscal policies that stimulate the economy must go and it is time for 'belt tightening.' This moral metaphor, which appeals strongly to popular common sense (Jabko 2013, 706), was repeated in two news articles at this time (HS July 23, 2010; HS, July 29, 2010).

Articles dealing with budgetary planning in March 2012 were illuminating in terms of the pro-austerity frame adopted by HS and top policy elites since 2010. In an article titled 
'Defender of rigorous austerity,' Jörg Asmussen, member of the ECB’s executive board, was quoted as saying that 'there is no alternative' to 'hard policies,' even though some economists have criticized them (HS, March 26, 2012). In another article, PM Katainen was reported as on a skiing trip in northern Finland together with Asmussen and other luminaries from the EU and WTO. This event, described by Katainen as 'international brain storming,' prompted HS to observe that 'the eurozone has adopted a policy of strict austerity,' the goal of which 'is to build a foundation for upcoming growth of production and employment.' It was acknowledged that 'heavy cut-backs reduce aggregate demand in the beginning,' but this counter-argument was pushed aside with the conclusion that 'Finland has to give a credible display of curbing public debt’ (HS, March 24, 2012).

Besides EU institutions, many other sources used by HS lent public support to austerity. For example, $H S$ focused on the views of Moody's, a well-known international credit rating agency, according to which Finland needs to 'curb its public finance deficits' if it wishes to maintain its triple-A credit rating and credibility (HS, March 16, 2010).

While eurozone policies apply to all member states, the willingness of leading Finnish politicians to follow them to the letter can be understood better when set against the ideational legacies of its economic structure. The history of Finland as a small northern capitalist economy that relies on export-driven growth (e.g., forestry, pulp and paper industries, metal industries, and electronics) has helped create an intellectual climate in which mainstream economic thought and practice by default emphasize 'the competitiveness and profitability of the export industry' (Pekkarinen 1989, 328). This amplified the non-Keynesian aspects of the Finnish economic policy model during the economic crises of the 1990s and 2010s. In line with the Finnish tradition of emphasizing the importance of balanced budgets and a harsh monetary policy (Pekkarinen and Heinonen 1998, 90), the MoF and EU emerged as the primary definers of the crisis, demanding financial discipline and reforms meant to strengthen competitiveness and public finances.

\section{Consensus around structural reforms}

Austerity is by its nature punitive and disciplinary, but it also has political appeal through its associations with ideas about shared sacrifice and collective obligation (Jabko 2013), which have helped to secure consent for it in the aftermath of crises (Stanley 2014). Yet, public calls for austerity are typically accompanied by calls for 'structural reforms,' which provide visions 
of economic growth through supply-side measures. The idea of structural reforms has been a key part of Finnish economic policy since the depression of the 1990s, when the MoF started to emphasize the need to reform, for example, the labor market and pension system to improve productivity and national competitiveness (Määttä 2005, 243-244).

Finnish elites referred to the need to, for example, raise the retirement age, ensure the competitiveness of Finnish exports through modest wage increases, or loosen state regulation of businesses. The dominant agents offered these structural reforms as developments that would lead the way to a healthier economy. Indeed, while Finnish political elites support austerity policies, they tend to shy away from discussions about spending cuts, preferring instead to focus on the notion of structural reforms, which comes across as less divisive and more in line with the attempt to bring all parties consensually together. The idea of structural reforms is, therefore, akin to the idea of 'national competitiveness,' which has, since the economic crisis of the 1990s, unified political elites and various political actors behind a common goal (Kananen and Kantola 2009).

In HS, references to the need to make structural reforms already appeared in stories in 2009 and 2010, but the idea became much more prevalent thereafter (see figure 3). This coincides with the fact that in late 2010, the MoF began to demand structural reforms and an end to stimulus measures (Salo 2017, 160-161). The theme of structural reforms as the primary solution to the crisis informed economic policy discussions in HS throughout the years 20112014. This is in line with findings that have seen calls for structural reforms being the dominant reasoning in European-wide coverage of the euro crisis (Ojala and Harjuniemi 2016). 


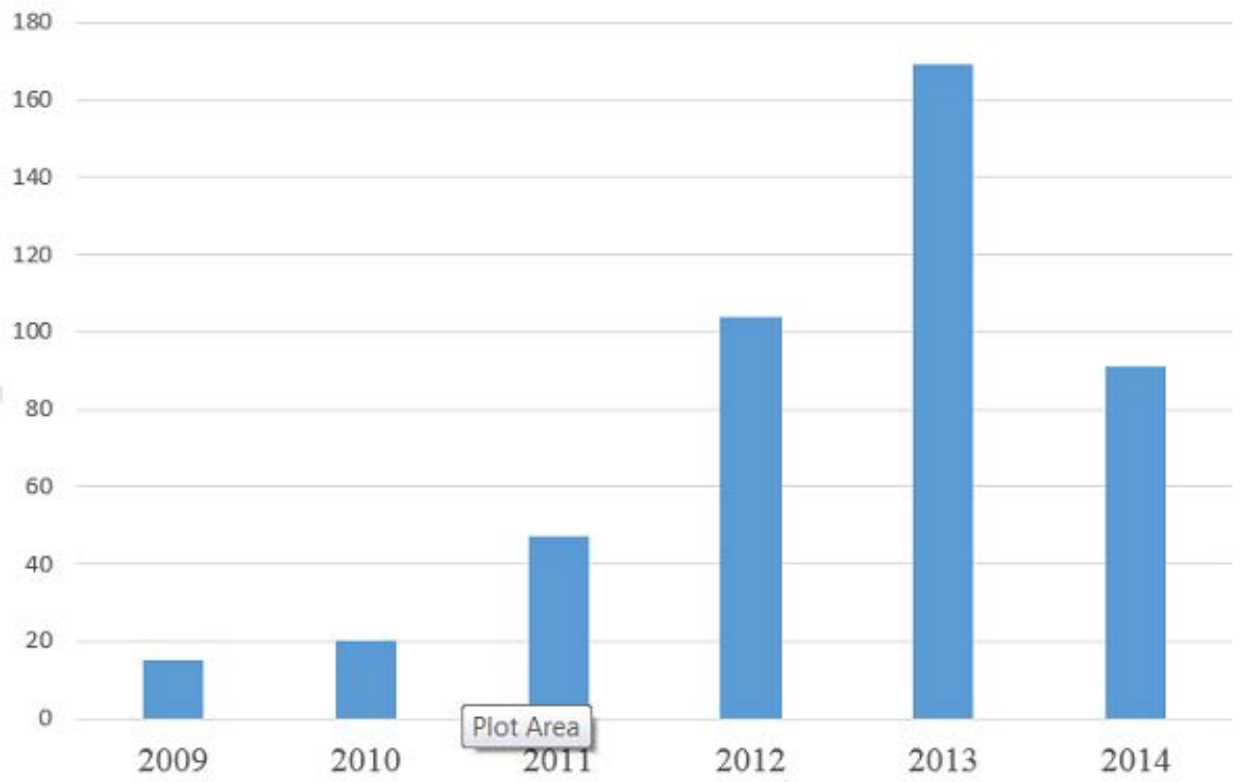

FIGURE 3. Articles with the word "Structural reforms," 2009-2014.

The call for structural reforms highlighted an explicit attempt to forge a political consensus in Finland that identified excessive regulation and market rigidity as the main obstacles to overcoming economic problems and encourage politicians to see themselves first and foremost as business-friendly reformists. This MoF-led consensus cuts across party lines (Salo 2017, 163). In 2013, PM Katainen spoke about the necessity of increasing 'confidence' between the government, the opposition, and the heads of labor market organizations. The aim of this effort was 'to create an atmosphere in which Finland can agree to make those structural reforms that will extend working careers and increase the supply of labor' (HS, August 6, 2013). The same refrain was repeated by Social Democratic Finance Minister Urpilainen and members of the main opposition party (the Centre Party) in numerous HS articles at the time (HS, August 10, 2013).

\section{Marginalized critical voices}

While the above-mentioned actors and ideas clearly dominated the pages of $H S$, the newspaper allowed some space for criticism of the dominant economic policy. Criticism of the mainstream position can be roughly divided into two categories: partial and substantial. Partial ideational criticism merely questioned the timing of austerity or the size of the reductions, not their necessity. For instance, several Social Democratic ministers expressed concern over the fate of the welfare state, but such concerns did not challenge the prevailing anti-stimulus consensus to which the Social Democrats had also committed. 
More substantial criticisms were voiced by four different groups of actors: certain noted international academic economists (Joseph Stiglitz and Paul Krugman), individual Finnish academic economists, the Labour Institute of Economic Research, and some left-leaning politicians who raised the issue of increasing economic inequality. Stiglitz and Krugman were cited on three occasions as critics of austerity, and they lent their authority to pro-stimulus arguments in articles published after the turning point of the summer of 2010, when stimulus had been officially rejected in the eurozone (HS, March 21, 2011; HS, August 2, 2012; HS, August 10, 2012). One HS article went against the grain by citing the view of the Labour Institute of Economic Research, which called into question the goal of controlling budget deficits because of austerity’s adverse effects on the economy (HS, 19 March 2013).

While most Finnish economists quoted in HS expressed satisfaction with fiscal consolidation, one exceptional article (HS, March 27, 2014) published towards the end of our data gathering period gave two Finnish academic professors space to criticize the dominant policy line. Pertti Haaparanta from Aalto University questioned the idea that austerity would restore market confidence in the Finnish economy. He referred to the notion of a 'confidence fairy,' made famous by Krugman:

The danger is that the Finnish government will endanger looming economic growth by making the same mistakes that brought the eurozone into recession. Tightening of fiscal policy did not in itself restore confidence in the eurozone, and it might not do it for Finland either. It seems that the Finnish government also believes in the confidence fairy.” (HS, March 27, 2014)

This was the only occasion in which reference was made to an alternative, critical viewpoint concerning the underlying private-sector causes behind the eurozone crisis in our data; overwhelmingly, the causes of the crisis were not discussed, or else they were implicitly or explicitly assumed to have been caused by government overspending. In the same article, Matti Tuomala from Tampere University asked a pertinent question from a marginalized Keynesian perspective: 'How is it possible to promote employment and economic growth by reducing demand?' Hence, it can be said that the economic policy public sphere constructed by $H S$ was not monolithic. Yet, the critical voices were sparse and sporadic. Beyond the pages 
of $H S$, this suggests that there is no powerful, unified political formation that could ideationally contest the MoF-led hegemonic economic policy bloc in Finland.

\section{Conclusions}

Many key institutional researchers have in recent decades been motivated by the so-called ideational turn, which refers to perspectives that treat ideas as 'both objects of inquiry and significant categories [...] in their own right' (Blyth 2002, 17). Ideational scholars have been interested in the dynamic aspects of ideas, that is, in how ideas instigate institutional changes (Blyth 2002; Schmidt 2010). Recently, this perspective has increasingly been perceived of as being out of date due to the realization that the post-2008 crisis has not led to a paradigm shift in the political economy of advanced capitalist countries à la the destruction of Fordist Keynesianism in the 1970s. Consequently, Jessop (2014) emphasizes that neoliberal ideas are not 'free-floating and disembodied causal forces,' but rooted in powerful social agents, organizational routines, and institutions, while Blyth and Matthijs (2017) have distanced themselves from ideational institutionalism by emphasizing the need to analyze the institutional logics and limits of 'macroeconomic regimes' (such as Fordist Keynesianism, neoliberalism, and possibly neo-nationalism) in an attempt to explain why shifts from one regime to another take place.

These divergent post-2008 analyses and debates show that political economists and institutionalist researchers are constantly seeking a balance between 'ideational' and 'institutional' elements in their explanations. Based on our analysis of the Finnish context, it seems clear that ideas cannot be abstracted from the long-standing institutional structures and practices to which they are organically connected. This dynamic has remained in place during the post-2008 global economic crisis conjuncture. Indeed, as scholars interested in the power of ideas have duly noted, any new ideas spurred by a crisis of such magnitude come into conflict with the vested interests of established institutions and dominant ideational paradigms (Carstensen and Schmidt 2014, 345-346; Baker and Underhill 2015).

Our analysis shows that as soon as the eurozone crisis deepened and the indebtedness of the Finnish state increased, stimulatory fiscal policies and discourses effectively flew out of the window (see also Salo 2017). This has been followed by wholly neoliberal policy recommendations, including public spending cuts, debt reduction, structural reforms, and other initiatives to revive national competitiveness through reducing labor costs. Accordingly, 
instead of ideational change and contestation, the post-2008 public discussion in Finland demonstrates the remarkable stability of the main institutions, which continue to dominate economic policies regardless of what has happened globally in recent decades. Alternative frames for economic policy are conspicuously absent in mainstream discussions as a result of a combination of domestic and international factors that amplify one another.

First, with regard to the adoption of Keynesian ideas, Finland offers an 'intriguing negative case' (Pekkarinen 1989, 311, 345) that stands in contrast to the other Nordic countries. The main domestic institutions responsible for drawing the contours of Finnish economic policy, the Bank of Finland and the MoF, have traditionally promoted 'treasury view' type ideas that highlight the importance of sound finance (Pekkarinen and Heinonen 1998). In comparison to the above-mentioned countries, the central bureaucracies in charge of designing economic policies in Finland have been resistant to political control (Pekkarinen 1989, 324, 344). This feature has continued via the pronounced power of the MoF before and during the global economic crisis and euro crisis. As Salo notes (2017, 162-163), the leadership of the main government parties, the right-wing National Coalition Party and the Social Democratic Party, coalesced around an MoF consensus during the euro crisis. We found that the MoF's economic assessments and policy prescriptions were treated as virtually sacrosanct, and government politicians, regardless of party, did not challenge them. This is hardly surprising, as the main political parties, including the Social Democrats, had already subscribed to the neoliberal agenda of competitiveness and structural reforms in the late 1980s (Kantola and Kananen 2013, 813-815). Thus, any deviations from the MoF-directed policy line favoring austerity and structural reforms were dismissed as irresponsible or unworthy of consideration, sometimes mocked and rarely represented.

Second, Finland, as a member of the eurozone, has relinquished its economic sovereignty to the EMU and associated financial political agreements, which further demands submitting to tightened budgetary discipline. Accordingly, Finland agreed in 2013 not to exceed structural deficits of $0.5 \%$ and public debt over $60 \%$ of the GDP (Kaitila and Ronkainen 2015, 5). The intention of these limits is to support export cost competitiveness, which translates into wage restraints, attempts to boost productivity, and other supply-side reforms, irrespective of their negative consequences, such as rising unemployment, a low investment rate, and deficiency of aggregate demand. These institutional straightjackets have had a similar chilling effect on the ideational contestation of dominant economic policies, which is evident in the powerful 
role of the MoF, and furthered by the need of the Finnish state to demonstrate its credibility before international financial markets.

These institutional forces and voices had a marked presence in HS budgetary news and commentary between 2009 and 2014, and they need to be kept in mind when assessing the ways in which the mainstream media covers Finnish economic policy. HS's budgetary news gave, at best, limited space for ideas that challenged the dominant paradigm and institutions. Its views on the economic crisis overwhelmingly represented a narrow range of elite perspectives. Our research is thus in line with media research on news production in general and news concerning austerity since 2008 in particular (Mylonas 2012; Harjuniemi, Herkman, and Ojala 2015; Berry 2016), according to which the mainstream media over-emphasizes 'powerful and privileged institutional positions' (S. Hall et. al 1978, 58). Though elites do not form a conflict-free political singularity (Davis 2003), when the media reports on issues where a strong consensus prevails among the elites, such as in Finland regarding the country's economic policies, it is in a sense not ideologically skewed; instead, such views 'accurately reflect and represent the prevailing structure and a mode of power' (S. Hall, Connell, and Curti 1976, 92). Indeed, our results support the conclusions of other scholars that journalists do not feel compelled to present opposing views on issues that are characterized by a strong elite consensus (Hallin 1984, Gibson 2004; Lounasmeri 2010). When such a consensus prevails, journalists often 'feel it their responsibility to act as advocates or ceremonial protectors of consensus values' (Hallin 1984, 21).

Through such institutional media logics, which certainly have in recent decades become more commercialized and business-oriented, the news media in advanced capitalist countries has increasingly become supportive of a neoliberally defined social and economic reality (Phelan 2014; Conboy 2017). This can be interpreted as a shift towards what Crouch $(2004,4)$ has defined as 'post-democracy,' where politics are more constrained, offering fewer possibilities for presenting alternatives through democratic discussion, and shaped by 'interaction between elected governments and elites that overwhelmingly represent business interests.' In our case, this manifests most clearly in how Finnish ministers (also Social Democratic ones) and business elites publicly castigate former governments and politicians for their weak 'crisis consciousness,' meaning their unwillingness to follow through on structural reforms that would further undermine the power of organized labor. 
The central weakness of this discourse is that it re-enforces a technocratic view of politics, where democratic discussion and contestation are considered problems that need to be resolved through business-friendly reforms, which are non-negotiable. This has weakened the overall legitimacy of democratic capitalism (Streeck 2014). By presenting austerity and market-oriented structural reforms as ideas that cannot be challenged, the mainstream media, including the leading Finnish newspaper analyzed here, are not fulfilling their self-proclaimed democratic functions. Instead, they are working as organs of a post-democratic public sphere, with troubling political implications, especially in light of the prospect of an emerging neonationalist regime that seeks to establish itself on the ruins of neoliberalism (Blyth and Matthijs 2017).

\section{Notes}

1. At the beginning of the parliamentary term, the government decides on a framework for government expenditures for the four-year parliamentary term. The allocation of money is revised yearly in March-April (Ministry of Finance 2017). Spring 2011 was left out because it was incompatible with the rest of the data due to the parliamentary elections (National Audit Office of Finland 2012, 24).

2. We used the keywords leik* (cut), elvyt* (stimulate), *sopeut* (consolidate), kirist* (tighten) and kehy* (frame) when searching for articles dealing with the yearly budget revisions. The keywords leik* (cut), elvyt* (stimulate), sopeut* (consolidate), kirist* (tighten), budjet* (budget) and talousarvio* (budget) were used when searching for articles dealing with the MoF's budget proposals.

\section{References}

Baker, Andrew, and Geoffrey R.D. Underhill. 2015. "Economic Ideas and the Political Construction of the Financial Crash of 2008." British Journal of Politics and International Relations 17 (3): 381-390. doi:10.1111/1467-856X.12072.

Berry, Mike. 2016. "No Alternative to Austerity: How BBC Broadcast News Reported the Deficit Debate.” Media, Culture and Society 38 (6): 844-863. doi:10.1177/0163443715620931.

Blyth, Mark. 1997. “'Any More Bright Ideas?’ The Ideational Turn of Comparative Political Economy.” Comparative Politics 29 (2): 229-250. doi:10.2307/422082.

Blyth, Mark. 2001. "The Transformation of the Swedish Model: Economic Ideas, Distributional Conflict, and Institutional Change.” World Politics 54 (1): 1-26. http://www.jstor.org/stable/25054172.

Blyth, Mark. 2002. Great Transformations. Economic Ideas and Institutional Change in the Twentieth Century. New York: Cambridge University Press. 
Blyth, Mark. 2013. Austerity: The History of a Dangerous Idea. New York: Oxford University Press.

Blyth, Mark, Oddny Helgadottir, and William Kring. 2016. "Ideas and Historical Institutionalism.” In The Oxford Handbook of Historical Institutionalism, edited by Orfeo Fioretos, Tulia G. Falleti, and Adam Sheingate, 142-162. New York: Oxford University Press.

Blyth, Mark. 2017. "Esipuhe Suomennokseen: Talouskuri ei toimi Suomessakaan.” [Preface to the Finnish Translation of Austerity] in Talouskuri: Vaarallisen opin historia. [Austerity: The History of a Dangerous Idea]. Tampere: Vastapaino.

Blyth, Mark, and Matthias Matthijs. 2017. "Black Swans, Lame Ducks, and the Mystery of IPE's Missing Macroeconomy.” Review of International Political Economy 24 (2): 203-231. doi:10.1080/09692290.2017.1308417.

Campbell, John. 1998: "Institutional Analysis and the Role of Ideas in Political Economy.” Theory and Society 27 (3): 377-409. http://www.jstor.org/stable/657900.

Carstensen, Martin B., and Vivien A. Schmidt. 2016. "Power Through, Over and In Ideas: Conceptualizing Ideational Power in Discursive Institutionalism.” Journal of European Public Policy 23 (3): 318-337. doi:10.1080/13501763.2015.1115534.

Conboy, Martin. 2017. "Journalism and the Democratic Market Society.” Journalism Studies 18 (10): 1263-1276. doi:10.1080/1461670X.2017.1336935.

Crouch, Colin. 2004. Post-Democracy. Cambridge: Polity Press.

Davis, Aeron. 2003. "Whither mass media and power? Evidence for a critical elite theory alternative.” Media, Culture \& Society 25 (5): 669-690. doi: 10.1177/01634437030255006.

Davies, William. 2016. “The New Neoliberalism.” New Left Review 101 (Sep.Oct. 2016): 121-134. https://newleftreview.org/II/101/william-davies-the-new-neoliberalism

Farrell, Henry, and John Quiggin. 2012. "Consensus, Dissensus and Economic Ideas: The Rise and Fall of Keynesianism During the Economic Crisis.” http://www.henryfarrell.net/Keynes.pdf

Fürsich, Elfriede. "In Defence of Textual Analysis: Restoring a Challenged Method for Journalism and Media Studies.” Journalism Studies 10 (2): 232-252. doi:10.1080/14616700802374050.

Gibson, Timothy A. 2004. "Covering the World-Class Downton: Seattle’s Local Media and the Politics of Urban Redevelopment." Critical Studies in Media Communication 21 (4): 283-304. doi:10.1080/0739318042000245336.

Hall, Peter A. 1989. "Introduction.” in The Political Power of Economic Ideas: Keynesianism Across Nations, edited by Peter A. Hall, 3-27, Princeton: Princeton University Press.

Hall, Peter A. 1993. "Policy Paradigms, Social Learning, and the State: The Case of Economic Policymaking in Britain.” Comparative Politics 25 (3): 275-296. doi: 10.2307/422246.

Hall, Stuart, Ian Connell, and Lidia Curti Connell. 1976. "The 'Unity' of Current Affairs Television.” In Culture and Domination: Cultural Studies 9: Working Papers in Cultural Studies, 51-93.

Hall, Stuart, Chas Critcher, Tony Jefferson, John Clarke, and Brian Roberts. 1978. Policing the Crisis: Mugging, The State, and Law and Order. London: Macmillan.

Hallin, Daniel C. 1984. "The Media, the War in Vietnam, and Political Support: A Critique of the Thesis of an Oppositional Media.” The Journal of Politics 46 (1): 2-24. http://www.jstor.org/stable/2130432

Harjuniemi, Timo, Juha Herkman, and Markus. Ojala. 2015. ”Eurokriisin politisoituminen suomalaisissa sanomalehdissä 2010-2012.” [The Politicization of the Euro 
Crisis in Finnish Newspapers in 2010-2012]. Media ja Viestintä 38 (1): 1-22.

https://journal.fi/mediaviestinta/article/view/62100.

Hay, Colin. 2001. "The Crisis of Keynesianism and the Rise of Neoliberalism in Britain.” In The Rise of Neoliberalism and Institutional Analysis, edited by John Campbell and Ove K. Pedersen, 193-219. Princeton: Princeton University Press,

Heikkinen, Sakari, and Seppo Tiihonen. 2010. Hyvinvoinnin turvaaja:

Valtiovarainministeriön historia 3 [The Guardian of Welfare: The History of the Ministry of Finance, part 3]. Helsinki: Edita.

Herman, Edward S., and Robert W. McChesney. 1997. The Global Media. The New Missionaries of Corporate Capitalism. London: Cassell.

Jabko, Nicolas. 2013. “The Political Appeal of Austerity.” Comparative European Politics 11 (6): 705-712. https://link.springer.com/article/10.1057/cep.2013.21

Jessop, Bob. 2014. “A Specter is haunting Europe: a neoliberal phantasmagoria.” Critical Policy Studies 8 (3): 352-355. doi: http://dx.doi.org/10.1080/19460171.2014.944368.

Kaitila, Joel, and Antti Ronkainen. 2015. Talouskurista autonomiaan. Euromaiden omaehtoiset toimet liikkumavaran lisäämiseksi. [From Austerity to Autonomy. The Independent Actions of Eurozone Countries to Increase Leeway.] Vasemmistofoorumi, raportteja 2/2015. http://vasemmistofoorumi.fi/julkaisut/tutkimusraportit/joel-kaitila-anttironkainen-talouskurista-autonomiaan-euromaiden-omaehtoiset-toimet-liikkumavaranlisaamiseksi-2015/

Kananen, Johannes, and Anu Kantola. 2009. "Kilpailukyky ja tuottavuus: Kuinka uudet käsitteet saavuttivat hallitsevan aseman hyvinvointivaltion muutoksessa” [Competiveness and Productivity: How Did New Concepts Achieve a Dominant Position in the Transformation of the Welfare State]. In Ajatuksen voima: ideat hyvinvointivaltion uudistamisessa [The Power of an Idea: The Role of Ideas in the Transformation of the Welfare State], edited by Johannes Kananen, and Juho Saari, 119-153. Helsinki: Minerva Kustannus.

Kantola, Anu, and Johannes Kananen. 2013. "Seize the Moment. Financial Crisis and the Making of the Finnish Competition State.” New Political Economy 18 (6): 811-826. doi:1080/13563467.2012.753044.

Koning, Edward A. 2016. "The Three Institutionalisms and Institutional Dynamics: Understanding Endogenous and Exogenous Change.” Journal of Public Policy 36 (4): 639664. doi:10.1017/S0143814X15000240.

Kuismanen, Mika, and Mikko Spolander. 2012. "Finanssikriisi ja finanssipolitiikka Suomessa.” [The Financial Crisis and Fiscal Policy in Finland]. Kansantaloudellinen aikakauskirja 108 (1): 69-80.

http://www.taloustieteellinenyhdistys.fi/images/stories/kak/KAK12012/kak12012kuismanen. pdf.

Lounasmeri, Lotta. 2010. Kansallisen konsensuskulttuurin jäljillä [Searching for the National Consensus Culture]. PhD diss., University of Helsinki.

Ministry of Finance. 2009. “Talousarvioesitys 2010” [“Budget Proposal for 2010”]. Ministry of Finance.

http://budjetti.vm.fi/indox/sisalto.jsp;jsessionid=983E9A79D735057BC3C5932EFD97ECBD ?year=2010\&lang=fi\&maindoc=/2010/TAE/he/he. xml\&opennode $=0: 1: 3$ :

Ministry of Finance. 2010. “Talousarvioesitys 2011” [Budget Proposal for 2011]. Ministry of Finance. http://budjetti.vm.fi/indox/sisalto.jsp?year=2011\&lang=fi\&maindoc=/2011/TAE/he/he.xml\& opennode $=0: 1: 3: 5$ : 
Ministry of Finance. 2017. "Spending Limits in Central Government Finances and the Budget.” Accessed 22 May 2017. http://vm.fi/en/spending-limits-in-central-governmentfinances-and-the-budget.

Mylonas, Yiannis. 2012. "Media and the Economic Crisis of The EU: The ‘Culturalization' of A Systemic Crisis and Bild-Zeitung’s Framing of Greece.” Triple C: Communication, Capitalism and Critique: Journal for a Global Sustainable Information Society 10 (2): 646-671. http://www.triple-c.at/index.php/tripleC/article/view/380.

Määttä, Seppo. "Strategian ja strategisen information tulkintahorisontteja: Case Valtiovarainministeriö” [Interpretative Horizons on Strategy and Strategic Formation: Case Ministry of Finance]. PhD diss., Turku School of Economics and Business Administration.

National Audit Office of Finland. 2012. "National Audit Office's separate report to Parliament on the audit of the final central government accounts. Translation of National Audit Office’s separate report to Parliament, R14/2012 vp.” Accessed 22 May 2017. https://www.vtv.fi/en/publications/nao_s_reports_to_parliament/2012/national_audit_office_s _separate_report_to_parliament_on_the_audit_of_the_final_central_government_accounts.52 24.xhtml

Nordicom. 2017. "Top 20 Daily Paid-for Newspapers in the Nordic Countries by Circulation 2014 - Nordic Top List.” Nordicom. Accessed 11 October 2017. http://www.nordicom.gu.se/en/statistics-facts/media-statistics.

Ojala, Markus, and Timo Harjuniemi. 2016 "Mediating the German Ideology: Ordoliberal Framing in European Press Coverage of the Eurozone Crisis.” Journal of Contemporary European Studies 24 (3): 414-430. doi:10.1080/14782804.2015.1135109.

Pekkarinen, Jukka. 1989. "Keynesianism and the Scandinavian Models of Economic Policy.” In The Political Power of Economic Ideas. Keynesianism across Nations, edited by Peter A. Hall, 311-347. Princeton: Princeton University Press.

Pekkarinen, Jukka, and Visa Heinonen. 1998. "Talouspolitiikka ja kansantaloustieteellinen asiantuntemus Suomessa” [Economic Policy and Economic Expertise in Finland]. In Asiantuntemuksen politiikka: Professiot ja julkinen valta Suomessa [The Politics of Expertise: Professions and Public Power in Finland], edited by Juri Mykkänen, and Ilpo Koskinen, 84-100. Helsinki: Helsinki University Press. Macmillan.

Phelan, Sean. 2014. Neoliberalism, Media and the Political. London: Palgrave

Salo, Sanna. 2017. "The Curious Prevalence of Austerity: Economic Ideas in Public Debates on the Eurozone Crisis in Ireland and Finland, 2008-2012.” PhD Diss., European University Institute.

Schranz, Mario, and Mark Eisenegger. 2011. "The Media Construction of the Financial Crisis in a Comparative Perspective - An Analysis of Newspapers in the UK, USA and Switzerland Between 2007 and 2009.” Swiss Journal of Sociology 37 (2): 241-258.

Schifferes, Steve, and Richard Roberts. 2015. “Editor's Introduction.” In The Media and Financial Crises. Comparative and Historical Perspectives, edited by Steve Schifferes and Richard Roberts, xv-xxii. Abingdon: Routledge.

Schmidt, Vivien A. 2008. "Discursive Institutionalism: The Explanatory Power of Ideas and Discourse.” The Annual Review of Political Science 11: 303-326. doi:10.1146/annurev.polisci.11.060606.135342.

Schmidt, Vivien A. 2010. "Taking Ideas and Discourse Seriously: Explaining Change Through Discursive Institutionalism as the Fourth 'New Institutionalism.'” European Political Science Review 2 (1): 1-25. doi:10.1017/S175577390999021X.

Schmidt, Vivien A., and Mark Thatcher. 2014. "Why Are Neoliberal Ideas So Resilient in Europe’s Political Economy.” Critical Policy Studies 8 (3): 340-347. doi:10.1080/19460171.2014.926826. 
Stanley, Liam. 2014. “'We're Reaping What We Sowed': Everyday Crisis Narratives and Acquiescence in the Age of Austerity.” New Political Economy 19 (6): 895917. doi:10.1080/13563467.2013.861412.

Streeck, Wolfgang. 2014 “How Will Capitalism End?” New Left Review 87 (MayJun. 2014): 35-64. https://newleftreview.org/II/87/wolfgang-streeck-how-will-capitalism-end

Streeck, Wolfgang. 2015. "Heller, Schmitt and the Euro.” European Law Journal 21 (3): 361-370. doi:10.1111/eulj.12134.

Quiggin, John. 2010. Zombie Economics: How Dead Ideas Still Walk among Us. Princeton: Princeton University Press.

Vesa, Juho. 2016. "Päätöksenteon avoimuus ja medioituminen Suomen konsensusdemokratiassa." [The Mediatization and Openness of Decision-Making in the Finnish Consensus Democracy]. PhD diss., University of Helsinki.

Whiteside, Heather. 2016. "Neoliberalism as Austerity: The Theory, Practice and Purpose of Fiscal Restraint since the 1970s." In The Handbook of Neoliberalism, edited by Simon Springer, Kean Birch, and Julie MacLeavy, 361-370. New York: Routledge.

Widmaier, Wesley. 2016. “The Power of Economic Ideas - Through, Over and In Political Time: The Construction, Conversion and Crisis of the Neoliberal Order in the US and UK.” Journal of European Public Policy 23 (3): 338-356.

doi:10.1080/13501763.2015.1115890. 